\title{
Assessment of quality of care provided at a tertiary hospital of Sikkim by patient's degree of responsiveness
}

\author{
Hafizur Rahman ${ }^{1 *}$, Ezzat Khalda ${ }^{2}$
}

\begin{abstract}
${ }^{1}$ Department of Obstetrics and Gynecology, Sikkim Manipal Institute of Medical Sciences-Sikkim Manipal University, $5^{\text {th }}$ Mile, Tadong, Gangtok, Sikkim, India

${ }^{2}$ Department of Radio-diagnosis, Sikkim Manipal Institute of Medical Sciences- Sikkim Manipal University, $5^{\text {th }}$ Mile, Tadong, Gangtok, Sikkim, India
\end{abstract}

Received: 28 June 2019

Accepted: 05 August 2019

\section{*Correspondence:}

Dr. Hafizur Rahman,

E-mail: hafizezzy@gmail.com

Copyright: ( ) the author(s), publisher and licensee Medip Academy. This is an open-access article distributed under the terms of the Creative Commons Attribution Non-Commercial License, which permits unrestricted non-commercial use, distribution, and reproduction in any medium, provided the original work is properly cited.

\section{ABSTRACT}

Background: Quality of care is concerned with the interface between provider and patients, between health services and community. The aim of the current study was to evaluate the quality of provided health care and patient experiences at a tertiary hospital based on the concept of responsiveness.

Methods: This was a cross-sectional survey among reproductive women of Central Referral Hospital over a period of 5 months from August 2016 to December 2016. A pre-designed, pretested, self-administered response questionnaire on rate of service utilization using the WHO health system responsiveness module was used.

Results: A total of 450 women were approached and requested to participate during the study period of which 374 women completed the survey. According to the evaluation of in-patient care (Table 2), "able to change doctor if wanted" showed the lowest degree of responsiveness (52.7\%). A significant proportion of patients experienced discrimination for different reasons: $9.6 \%$ reported feeling they had been treated worse than others because of lack of money, while a similar proportion reported they had been discriminated for the language they speak or because they were having insurance from a company.

Conclusions: Health care access in terms of prolong waiting time in the reception and before being attended by doctor, difficulty to change doctor when wanted and discriminatory experiences were identified as priority areas for actions to improve responsiveness and patient satisfaction.

Keywords: Degree of responsive, Health care, Quality of care

\section{INTRODUCTION}

The state of Sikkim located in the eastern Himalayas became the $22^{\text {nd }}$ state of Indian union. It has four districts of which East is the most populous district with about $70 \%$ of total population of Sikkim. ${ }^{1}$ There is only one referral medical college hospital in entire Sikkim, the Central Referral Hospital (CRH) which is a teaching hospital of Sikkim Manipal Institute of Medical Sciences
(SMIMS), located in east Sikkim. The central Referral Hospital has a vision of providing quality health care to the population of Sikkim. ${ }^{2}$ The hospital is facing many challenges, one of which is quality of care, being frequent reporting in news papers and social media (voice of Sikkim, Face book etc). ${ }^{3}$ Quality of care is concerned with the interface between provider and patients, between health services and community. A quality perspective changes the focus of health systems development from 
establishing structures to addressing what happens in the structures. Central Referral Hospital has an excellent and coherent health care structures and infrastructure. Ensuring quality of service delivery is regarded as a second phase of health care transformation. ${ }^{4}$

Variations in perceptions of quality care occur as a result of heterogeneous nature of definition of quality, different socioeconomic groups, employment and environmental aspects like social organizational and technological context of service. ${ }^{5}$ Level of quality and satisfaction also depends on interpersonal aspects of care like clear information, communication and involvement of patient in decision making. It is further emphasized the importance of brining these issues to the attention of policy makers. $^{6-7}$

Patients' views are being given more and more importance in policy-making. Understanding populations' perceptions of quality of care is critical to developing measures to increase the utilization of health care services. $^{8}$

A population based survey was conducted in the inpatient of Central Referral Hospital to assess health system performance in terms of quality of care and interpersonal aspects of care based on patient's degree of responsiveness. Using WHO survey on Health system responsiveness modified according to local context, the aim of the current study was to evaluate the quality of provided health care and patient experiences at in-patient department of Central Referral Hospital based on the concept of responsiveness. ${ }^{9}$

\section{METHODS}

This was a cross-sectional survey among reproductive women admitted in Gynecology in patient Department of Central Referral Hospital over a period of 5 months from August 2016 to December 2016. A pre-designed, pretested, self-administered response questionnaire on rate of service utilization using the WHO health system responsiveness module (with a little modification according to local context) was used. ${ }^{9}$

Questionnaire was both in English and translated to local language. The quality of translations was independently verified by bilingual experts before final implementation. Questionnaire was pretested among twenty participants who were also included in the final analysis. Permission from appropriate authority was taken for the survey and informed written consent was taken from the women who participated in the study.

Women were approached to participate if they were above 18 years who were admitted in gynecology inpatient department, irrespective of their reason(s) for admission. Exclusions were participants who were not able to respond because of their severe ill health or who declined to participate.

\section{Outcome measures}

The questionnaire included in this survey used the health system responsiveness module (WHO Modified) with modification according to local context to suit the study. ${ }^{9}$

Responsiveness relates to patient's experiences with the health system, with a focus on the interpersonal aspects of the care, and differs from patient satisfaction, a construct that reflects people's expectations in addition to their experiences.

Questions covered the following aspects in relation to hospital inpatient care- convenient travel and waiting times, respectful treatment, involvement in decisions, choice of care provider, clarity of communication, confidentiality of personal information, surrounding, contact with outside world. Further participant were asked whether they felt they had been treated worse or discriminated for any of the following reasons: sex, age, lack of money, social class, ethnic group, type of illness.

\section{Data analysis}

The first stage of survey analysis included a descriptive analysis of the degree of responsiveness based on a set of variables that express the participant's degree of experience, according to five response levels ( $1=$ very bad to $5=$ very good). These item responses were dichotomised into "4" and "5" $=1$, and 1-3 =0. For each of the items, the degree of responsiveness were estimated by the percentage of "good" or "very good" answers and the percentage of positive answers to other dichotomous variables (yes or no), related to the health professional's skills, and adequacy of equipment in the care. Discriminatory experiences were summed up and converted into a binary variable with $1=$ indicating any of the six discriminatory experiences and $0=$ no such experiences.

\section{RESULTS}

A total of 450 women were approached and requested to participate during the study period. Forty one women $(9.1 \%)$ declined to give consent, while 35 women $(7.7 \%)$ did not return or complete the questionnaires. Of the 374 women who completed the survey, majority $(66.3 \%)$ was below 30 years, Nepali, married Hindu and belonged to rural region. Two third of the participants were house wives and half were from lower middle class. Table 1 presents the background characteristics of the participants.

According to the evaluation of in-patient care (Table 2), "able to change doctor if wanted" showed the lowest degree of responsiveness $(52.7 \%)$ among all the areas analyzed. Other low responsive areas pointed out by participants included waiting time to at the reception and before being attended by physician, conditions surrounding rooms and wards. While, the aspects related 
to "respectful treatment" like greeted and talked respectfully $(83.4 \%)$ and physical privacy respected $(89 \%)$ had the highest responsiveness scores.

Other good or very good aspects of care included involvement in decision makings and confidentiality of information as pointed out by participants.

Table 1: Demographic characteristics of the surveyed participant.

\begin{tabular}{|c|c|c|}
\hline Demographic characteristics & Number & Percentage \\
\hline \multicolumn{3}{|l|}{ Age (years) } \\
\hline Below 30 & 248 & 66.3 \\
\hline Above 30 & 126 & 33.7 \\
\hline \multicolumn{3}{|l|}{ Religion } \\
\hline Hindu & 242 & 64.7 \\
\hline Budhist & 69 & 18.4 \\
\hline Christian & 54 & 14.4 \\
\hline Others & 9 & 2.4 \\
\hline \multicolumn{3}{|l|}{ Ethnicity } \\
\hline Nepali & 284 & 75.9 \\
\hline Bhutia & 36 & 9.6 \\
\hline Lepcha & 27 & 7.2 \\
\hline Others & 27 & 7.2 \\
\hline \multicolumn{3}{|l|}{ Marital status } \\
\hline Married & 356 & 95.2 \\
\hline Unmarried & 18 & 4.8 \\
\hline \multicolumn{3}{|l|}{ Education } \\
\hline Primary $<5^{\text {th }} \mathrm{Std}$ & 59 & 15.8 \\
\hline $6^{\text {th }}-12^{\text {th }}$ & 222 & 59.4 \\
\hline University & 93 & 24.9 \\
\hline \multicolumn{3}{|l|}{ Occupation } \\
\hline Working/salaried & 84 & 22.5 \\
\hline Housewife & 275 & 73.5 \\
\hline Notworking/student & 15 & 4.0 \\
\hline \multicolumn{3}{|l|}{ Residence } \\
\hline Rural & 216 & 57.8 \\
\hline Urban & 158 & 42.2 \\
\hline \multicolumn{3}{|l|}{ Socio-economic class } \\
\hline Below poverty & 72 & 19.3 \\
\hline Lower middle & 191 & 51.1 \\
\hline Upper middle & 102 & 27.3 \\
\hline High & 9 & 2.4 \\
\hline
\end{tabular}

A significant proportion of patients experienced discrimination for different reasons: $9.6 \%$ reported feeling they had been treated worse than others because of lack of money, while a similar proportion reported they had been discriminated for the language they speak or because they were having insurance from a company.

Of all users, $8.8 \%$ reported they had been treated worse because of their lower social class and nature of the disease they were suffering (Table 3).
Table 2: Health care responsiveness (percentage of respondents who responded either good (score 4) or very good (score 5) in-patient care of the tertiary centre.

\begin{tabular}{|c|c|c|}
\hline Responsiveness on quality of care & Number & $\%$ \\
\hline \multicolumn{3}{|l|}{ Reception and waiting time } \\
\hline Waiting time at reception counter & 221 & 59.1 \\
\hline Attitude at reception & 291 & 77.8 \\
\hline Facilities at reception & 246 & 65.8 \\
\hline Waiting time to see physician & 234 & 62.6 \\
\hline \multicolumn{3}{|l|}{ Choice of healthcare provider } \\
\hline Able to see chosen doctor & 267 & 71.4 \\
\hline Able to stick to chosen doctor & 263 & 70.3 \\
\hline Able to change doctor if wanted & 197 & 52.7 \\
\hline Second opinion if wanted & 266 & 71.1 \\
\hline $\begin{array}{l}\text { Overall satisfaction with choice of } \\
\text { health care provider }\end{array}$ & 265 & 71.0 \\
\hline \multicolumn{3}{|l|}{ Respectful treatment } \\
\hline Greeted and talked to respectfully & 312 & 83.4 \\
\hline Physical privacy respected & 332 & 88.8 \\
\hline $\begin{array}{l}\text { Overall satisfaction in terms of } \\
\text { respectful treatment }\end{array}$ & 314 & 84.0 \\
\hline \multicolumn{3}{|l|}{ Clarity of communication } \\
\hline $\begin{array}{l}\text { Explained things in a way could } \\
\text { understand }\end{array}$ & 302 & 80.7 \\
\hline Enough time to ask questions & 296 & 79.1 \\
\hline $\begin{array}{l}\text { Overall satisfaction on } \\
\text { communication }\end{array}$ & 287 & 76.7 \\
\hline \multicolumn{3}{|l|}{ Involvement in decisions } \\
\hline $\begin{array}{l}\text { Freedom to discuss other } \\
\text { tests/treatment options }\end{array}$ & 278 & 74.3 \\
\hline $\begin{array}{l}\text { Allowed to be involved in making } \\
\text { decisions }\end{array}$ & 302 & 80.7 \\
\hline $\begin{array}{l}\text { Freedom to express a preference for } \\
\text { a treatment }\end{array}$ & 305 & 81.6 \\
\hline $\begin{array}{l}\text { Overall satisfaction in decision } \\
\text { makings }\end{array}$ & 293 & 78.3 \\
\hline \multicolumn{3}{|c|}{ Confidentiality of personal information } \\
\hline $\begin{array}{l}\text { Talks with doctor/nurse done } \\
\text { privately }\end{array}$ & 231 & 61.8 \\
\hline $\begin{array}{l}\text { Confidentiality of medical } \\
\text { information }\end{array}$ & 300 & 80.2 \\
\hline $\begin{array}{l}\text { Overall satisfaction in } \\
\text { confidentiality }\end{array}$ & 273 & 73.0 \\
\hline \multicolumn{3}{|l|}{ Cleanliness and surroundings } \\
\hline $\begin{array}{l}\text { Conditions surrounding rooms, } \\
\text { wards }\end{array}$ & 230 & 61.5 \\
\hline Sleeping conditions & 248 & 66.3 \\
\hline Cleanliness of the surroundings & 264 & 70.6 \\
\hline Overall satisfaction in cleanliness & 264 & 70.6 \\
\hline
\end{tabular}

\section{DISCUSSION}

Quality of any hospital depends on patient satisfaction is a very important aspect of medical care. Hospitals may have most renowned medical professionals and 
infrastructure facilities, but there are many factors and areas need to look that affect patient satisfaction. Managers may not be aware of all of them. In modern times when expectation from healthcare institutions are high and level of satisfaction is decreasing, leading to increased number of legal suits and physical manhandling of medical professionals, it is very important to know the variables affecting patient satisfaction. ${ }^{10}$ Hence it was decided to take up the present study with international standard WHO health system responsiveness module. ${ }^{9}$

Table 3: Percentage of patients who experienced some type of discrimination.

\begin{tabular}{|lll|}
\hline $\begin{array}{l}\text { Felt discrimination for } \\
\text { reason(s) of }\end{array}$ & Number & Percentage \\
\hline Age & 30 & 8.0 \\
\hline Sex & 18 & 4.8 \\
\hline Lack of money & 36 & 9.6 \\
\hline Lack of education & 24 & 6.4 \\
\hline Social class & 33 & 8.8 \\
\hline Nature of disease & 33 & 8.8 \\
\hline Race/Ethnicity & 27 & 7.2 \\
\hline Language & 36 & 9.6 \\
\hline Insurance holder & 36 & 9.6 \\
\hline Rural area & 18 & 4.8 \\
\hline Other reasons & 33 & 8.8 \\
\hline
\end{tabular}

Participants in this had lowest responsiveness (52\%) in "able to change physician", and long waiting time in reception and before being attended by physician which is quite low compared to report in another Indian super specialty hospital $(82 \%)$. In international surveys South Africa and other African countries (58\%) reported low responsiveness on waiting times compared to European countries $(81 \%){ }^{11}$

Major components identified for in-patient care responsiveness in this survey were highly correlated with respectful treatment, communication and autonomy, to dignity, confidentiality and involvement in decision making. Thus, from the perspective of health service users in our hospital, health care responsiveness was primarily related to options to change physician, waiting time in reception and before being attended by doctor. Each of the components got the lowest responsiveness ratings $(52 \%-61 \%)$ compared to health care provider's attitude in terms respectful treatment, clarity of communication and involvement in decision making (76$84 \%$. The degree of responsiveness found in this study was similar compared to another tertiary care centre survey and international Brazilian WHS (World health survey). ${ }^{10,11}$

Another problem identified in this study and also noted in the Brazilian WHS $^{11}$ was significant percentage of individuals who felt discrimination, which is one of the principal reasons for dissatisfaction in all aspects of provided health care. The principal factors of discrimination identified by respondents in this study were lack of money, language, having an insurance $(9,6 \%)$ and social class $(8.8 \%)$. De Souza et al. ${ }^{11}$ also found among the Brazilian WHS lack of money and social class as major factors of health care discrimination both in private and public care institutions. According to a qualitative study by Mashego and Peltzer discrimination was also identified among primary public care users. $^{12}$

Limitations of this study was in the study patient responsiveness on satisfaction were included from a single centre department. Survey sample is small and may not representative of the general population. The cross-sectional study design did not permit an investigation of the cause-effect relationship between responsiveness and independent variables. Further, studies are needed to identify the structure of health systems responsiveness domains in entire state with large number of subjects.

\section{CONCLUSION}

Health care access in terms of prolong waiting time in the reception and before being attended by doctor, difficulty to change doctor when wanted and discriminatory experiences were identified as priority areas for actions to improve responsiveness and patient satisfaction. Implications for policymaking include that the result from the survey can be used to prioritize efforts to improve service.

\section{Funding: No funding sources}

Conflict of interest: None declared

Ethical approval: The study was approved by the Institutional Ethics Committee

\section{REFERENCES}

1. Rahman H, Khalda E, Kar S, Kharka L, Bhutia GP. Knowledge of, attitudes toward and barriers to Practice of emergency contraception among women in Sikkim, India. Int $\mathbf{J}$ Gynaecol Obstet. 2013;122(2):99-103.

2. Central Referral Hospital. Vision and Mission. Available at: http://smu.edu.in/smims/hospital.html. Accessed on $25^{\text {th }}$ May, 2019.

3. The Voice of Sikkim. Available at: https:// www.facebook.com/thevoiceofsikkim/?hc_ref=SEA RCH\&fref $=$ nf, Accessed on $25^{\text {th }}$ May 2019.

4. Department of Public Services and Administration: Transforming Public Service, Delivery White Paper, 1997. Available at: http:// unpan1.un.org/ intradoc/ groups/public/documents/un/unpan005184.pdf, Accessed on $25^{\text {th }}$ May 2019.

5. Goldstein S, Price M. Utilisation of primary curative services in Diepkloof, Soweto. S Afr Med J. 1995;85(6):505-8.

6. Department of Health: South African Demographic and Health Survey, 2003. Available at: https:// 
dhsprogram.com/publications/publication-FR206DHS-Final-Reports.cfm. Accessed on $25^{\text {th }}$ May 2019.

7. Myburgh NG, Solanki GC, Smith MJ, Lalloo R. Patient satisfaction with health care providers in South Africa: the influences of race and socioeconomic status. Int $\mathrm{J}$ Qual Health Care. 2005;17(6):473-7.

8. Karl P. Patient experiences and health system responsiveness in South Africa. BMC Health Services Research. 2009;9:117-29.

9. Üstun TB, Chatterji S, Villanueva M, Celik LBC, Sadana R, Valentine N. World health organization, Multi-country Survey Study on Health and Responsiveness 2000-2001. Available at: https://www.who.int/responsiveness/papers/gpediscp aper37.pdf. Accessed on 25 ${ }^{\text {th }}$ May 2019.
10. Mishra PH, Mishra T. Study of patient satisfaction at a super specialty tertiary care hospital. Indian J Clin Pract. 2014;25(7):624-34.

11. Souza WV, Luna CF, De Souza PRB, Szwarcwald CL. Health care users' satisfaction in Brazil. Cad Saúde Pública. 2005;21:109-18.

12. Mashego TAB, Peltzer K. Community perception of quality of (primary) health care services in a rural area of Limpopo Province, South Africa: a qualitative study. Curationis. 2005;28(2):13-21.

Cite this article as: Rahman $\mathrm{H}$, Khalda $\mathrm{E}$. Assessment of quality of care provided at a tertiary hospital of Sikkim by patient's degree of responsiveness. Int J Reprod Contracept Obstet Gynecol 2019;8:3710-4. 